\title{
Implementasi Akad Produk Tabungan Rencana di PT. Bank Syariah Mega Indonesia Gallery Cianjur
}

\author{
Muhammad Wanto \\ Universitas Islam Negeri (UIN) Sunan Gunung Djati Bandung \\ muhammad_wanto@rocketmail.com
}

\begin{abstract}
Mudharabah savings is one product collector of funds applied to PT. Bank Syariah Mega Indonesia Gallery Cianjur which one is the product Savings Plan. On the product Savings Plan in PT. Bank Syariah Mega Indonesia Gallery Cianjur use mudharabah product and in doing transactions through book Savings Savings Plan Home / parent who uses contract wadiah.

That mechanism Savings Plan held by PT. Bank Syariah Mega Indonesia Gallery Cianjur is (1) Fill out the application form Individual customers / Institutions; (2) Fill out the contract form wadiah (primary Savings); (3) Fill out the deposit slip early; (4) Fill out the form mudharabah (Savings Plan); (5) Customer Savings Plan (mudharabah) regularly to conduct the transaction to go through Main Savings account book / parent use wadiah agreement; (6) Facilities Savings Plan that is certified as proof of ownership savings and checking account books as a book report. Legal basis in the product Savings Plan (mudharabah) No DSN. 02/DSN-MUI/IV/2000 on Saving. In perspective muamalah two covenants in the transaction was prohibited. In practice the contract products Savings Plan (mudharabah) it looks like there are two covenants in the transaction, the results of that research in the contract mechanism problems Savings Plan product in PT. Bank Syariah Mega Indonesia Gallery Cianjur is procedural only from banks and are in accordance with the fatwa of DSN No.02 and there are no violations in fikih muamalah.
\end{abstract}

Keywords: Mudharabah, wadiah, saving, Bank Syariah Mega Indonesia 


\begin{abstract}
Abstrak
Tabungan mudharabah adalah salah satu produk penghimpun dana yang diterapkan di PT. Bank Syariah Mega Indonesia Gallery Cianjur yaitu salah satunya adalah produk Tabungan Rencana. Pada produk Tabungan Rencana tersebut menggunakan akad mudharabah. Produk akad dalam Tabungan Rencana di buku Tabungan Utama/induk menggunakan akad wadi'ah. Adapun mekanisme Tabungan Rencana yang dilaksanakan PT. Bank Syariah Mega Indonesia Gallery Cianjur adalah (1) Mengisi form aplikasi nasabah Individual/Institusi; (2) Mengisi form akad wadi'ah (Tabungan Utama); (3) Mengisi slip setoran awal; (4) Mengisi form akad mudharabah (Tabungan Rencana); (5) Nasabah Tabungan Rencana (mudharabah) secara rutin untuk melakukan transaksinya harus melalui buku rekening Tabungan Utama/ induk yang menggunakan akad wadiah; (6) Fasilitas Tabungan Rencana yaitu mendapatkan sertifikat sebagai tanda bukti kepemilikan buku tabungan dan rekening koran sebagai buku laporan. Landasan hukum dalam produk Tabungan Rencana (mudharabah) yaitu Fatwa DSN No. 02/DSN-MUI/IV/2000 tentang Tabungan. Dalam prespektif muamalah, dua akad dalam satu transaksi itu dilarang. Dalam prakteknya akad produk Tabungan Rencana (mudharabah) itu kelihatan seperti ada dua akad dalam satu transaksi. Namun dari hasil penelitian ternyata itu hanya masalah teknis prosedural dari bank. Pada hakekatnya hal itu telah sesuai dengan fatwa DSN No. 02 dan tidak ada pelanggaran dalam fikih muamalah.
\end{abstract}

\title{
Pendahuluan
}

Islam yang dibawa oleh Rasulullah SAW. adalah agama humanistis artinya agama yang sangat menekankan dimensi kemanusiaan. Fungsi agama yang dibawa oleh Rasulullah SAW. adalah demi kepentingan manusia dan kemaslahatan manusia bukan untuk kepentingan Allah dan bukan untuk kemaslahatan bagi Allah. Sedangkan tujuan Islam yang dibawa oleh Rasulullah SAW. untuk meluruskan tingkah laku manusia di muka bumi seperti dalam hal pergaulan, transaksi perekonomian, jual beli dan lain-lainnya.

Maka kehadiran Bank Syariah di Indonesia salah satunya adalah untuk peredaran uang yang pengoperasianya disesuaikan dengan prinsipprinsip syariah. Bank syariah merupakan lembaga keuangan bank yang 
operasional dan produknya dikembangkan berlandaskan pada Al-Qur'an dan As-Sunnah. Bank syariah biasa disebut Islamic banking atau interest fee banking, yaitu suatu sistem perbankan dalam pelaksanaan operasional tidak menggunakan sistem bunga (riba), spekulasi (maisir), dan ketidakpastian atau ketidakjelasan (gharar) (Ali, 2008: 1).

Setelah di undangkanya UU No. 10 Tahun 1998, perkembangan bank syariah di Indonesia semakin pesat, yaitu ditandai dengan berdirinya bank syariah baru dengan sistem dual banking (dual banking system) antara lain, Bank IFI yang membuka cabang syariah pada tanggal 28 juni 1999, Bank Syariah Mandiri yang merupakan konversi dari Bank Susila Bakti (BSB), anak perusahaan Bank Mandiri, serta pendirian lima cabang baru berupa cabang syariah dari PT. Bank Negara Indonesia Tbk. Pada bulan Februari 2000, tercatat di Bank Indonesia bank-bank yang membuka cabang syariah, yakni: Bank Niaga, Bank BTN, Bank Mega, Bank BRI, Bank Bukopin, BPD Jabar dan BPD Aceh (Anshori, 2007:31).

Indonesia dalam kebijakan mengenai perbankan menganut dual banking system. Dual banking system maksudnya adalah terselenggaranya dua sistem perbankan (konvensional dan syariah secara berdampingan) yang pelaksanaanya diatur dalam berbagai peraturan perundangundangan yang berlaku. Sehingga yang terjadi adalah bank syariah tidak berdiri sendiri (mandiri), sehingga dalam operasionalisasinya masih menginduk kepada bank konvensional. Bila demikian adanya perbankan syariah hanya menjadi salah satu bagian dari program pengembangan bank konvensional.

Tujuan bank syariah secara umum adalah untuk mendorong dan mempercepat kemajuan ekonomi suatu masyarakat dengan melakukan kegiatan perbankan, finansial, komersial, dan investasi sesuai kaidah syariah (Anshori, 2007: 33).

Perbankan Syariah dalam melakukan kegiatan usahanya berdasarkan prinsip syariah, demokrasi ekonomi, dan prinsip kehati-hatian. Perbankan Syariah bertujuan menunjang pelaksanaan pembangunan nasional dalam rangka meningkatkan keadilan, kebersamaan dan pemerataan kesejahteraan rakyat (Muhammad, 2009: 4). 
PT. Bank Syariah Mega Indonesia Gallery Cianjur merupakan salah satu bank yang menyelenggarakan kegiatan perbankannya dengan menggunakan sistem bank syariah dalam operasinya dan menjalankan kegiatan usahanya berdasarkan prinsip syariah. Pada PT. Bank Syariah Mega Indonesia Gallery Cianjur menyediakan fasilitas sarana investasi.

Investasi bagi penyimpan dana berarti nasabah yang menyimpan dananya pada bank ini misalnya Tabungan Mudharabah atau Simpanan Mudharabah dianggap sebagai penyedia dana (shahibul maal), akan memperoleh hak bagi hasil dari usaha bank sebagai pengelola dana (mudharib) yang hasilnya tidak tetap dan tidak pasti, sesuai dengan besar kecilnya hasil usaha bank. Bagi hasil yang diterima penyimpan dana biasanya dihitung sesuai dengan lamanya dana tersebut mengendap dan dikelola oleh bank, bisa satu tahun, bisa satu bulan, bisa satu minggu dan bahkan bisa satu hari.

Tabungan Mudharabah adalah tabungan yang dijalankan berdasarkan akad mudharabah. Dalam hal ini, Bank Syariah bertindak sebagai mudharib (pengelola dana), sedangkan nasabah bertindak sebagai shahibul maal (pemilik dana). Bank syariah dalam kepastianya sebagai mudharib, mempunyai kuasa untuk melakukan berbagai macam usaha yang tidak bertentangan dengan prinsip syariah. Dari hasil pengelolaan dana mudharabah, Bank Syariah akan membagihasilkan kepada pemilik dana sesuai dengan nisbah yang telah disepakati dan dituangkan dalam akad pembukaan rekening (Karim, 2010: 347).

Dalam aktifitasnya sebagai penghimpun dana, PT. Bank Syariah Mega Indonesia Gallery Cianjur pada produk Tabungan Rencana yang menggunakan akad mudharabah dimana Bank Syariah bertindak sebagai mudharib (pengelola dana) dan nasabah bertindak sebagai shahibul maal (pemilik dana). Untuk fasilitas pada Tabungan Rencana PT. Bank Syariah Mega Indonesia Gallery Cianjur, PT. Bank Syariah Mega Indonesia Gallery Cianjur memberikan sertifikat sebagai kepemilikan rekening. Dari hasil wawancara dengan karyawan PT. Bank Syariah Mega Indonesia Gallery Cianjur yaitu Bapak R. Muhammad Ali Ridho (Relationship Officer) tanggal 25 April 2011 pada produk Tabungan Rencana di PT. Bank Syariah Mega Indonesia Gallery Cianjur penabungan secara rutin disyaratkan atau di- 
wajibkan untuk membuka Tabungan Utama yang menggunakan akad wadiah dan untuk transaksi Tabungan Rencana hanya dapat dilakukan melalui mekanisme autodebet dari Rekening Induk (Tabungan Utama).

\section{Gambar 1}

Skema Transaksi Tabungan Rencana

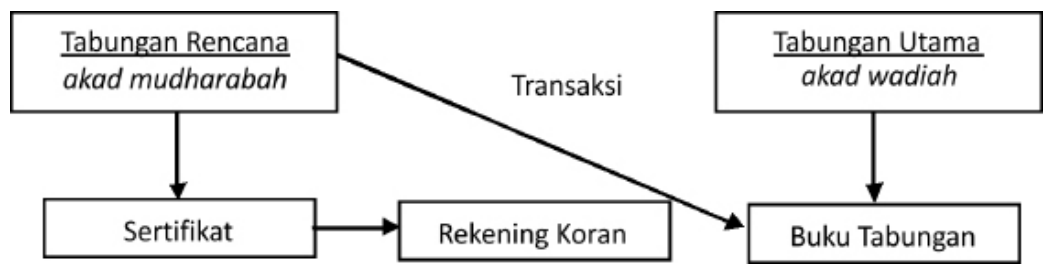

Dari latar belakang di atas, hal ini sangat menarik untuk diteliti lebih lanjut, dan menuangkanya dalam sebuah karya ilmiah dalam bentuk skripsi dengan judul “Implementasi Akad Produk Tabungan Rencana di PT. Bank Syariah Mega Indonesia Gallery Cianjur"

\section{Kerangka Pemikiran}

Indonesia adalah negara kepulauan terbesar di dunia yang memiliki beragam suku bangsa, bahasa, dan agama dengan jumlah penduduk sekitar 240 juta. Meskipun bukan negara Islam, indonesia merupakan negara dengan berpenduduk Muslim terbesar di dunia dengan jumlah penduduk beragama Islam 88 persen, Kristen 5 persen, Katolik 3 persen, Hindu 2 persen, Budha 1 persen. Semakin majunya sistem keuangan dan perbankan serta semakin meningkatnya kesejahteraan, kebutuhan masyarakat, khususnya Muslim, menyebabkan semakin besarnya kebutuhan terhadap layanan jasa perbankan yang sesuai dengan prinsip syariah.

Atas dasar dorongan kebutuhan masyarakat terhadap layanan jasa perbankan syariah, maka didirikanya bank syariah dan bank syariah pertama berdiri pada tahun 1992. Bank syariah adalah bank yang melaksanakan kegiatan usaha berdasarkan prinsip syariah, yaitu aturan perjanjian berdasarkan hukum Islam antara bank dan pihak lain untuk penyimpanan dana dan atau pembiayaan kegiatan usaha, atau kegiatan lainnya yang dinyatakan sesuai dengan syariah. Dalam menjalankan usahanya bank syariah menggunakan pola bagi hasil yang merupakan landasan utama dalam segala operasinya, baik dalam produk pendanaan, 
pembiayaan maupun dalam produk lainnya. Produk-produk bank syariah mempunyai kemiripan tetapi tidak sama dengan produk bank konvensional karena adanya pelarangan riba, gharar, dan maysir.

Dengan makin pentingnya peranan Bank Syariah sebagai lembaga keungan syariah maka efektifitas yang dilakukan oleh lembaga tersebut akan membawa pengaruh yang besar dalam suatu masyarakat yang semakin berkembang. Kerjasama antara masyarakat dengan pengusaha dengan dunia perbankan demikian majunya sehingga keduanya merupakan rekanan yang saling membantu satu sama lain.

Kerjasama dalam ekonomi Islam disebut dengan al-musyarakah yang mempunyai pengertian sebagai "akad kerjasama antara dua pihak atau lebih untuk suatu usaha tertentu di mana masing-masing pihak memberikan kontribusi dana (atau amal/expertise) dengan kesepakatan bahwa keuntungan dan resiko akan ditanggung bersama sesuai dengan kesepakatan (Antonio, 2009: 90).

Sedangkan menurut Adiwarman A. Karim, musyarakah adalah transaksi kerjasama yang dilandasi adanya keinginan para pihak yang bekerja sama untuk meningkatkan nilai aset yang mereka miliki secara bersama-sama (Karim, 2010: 102).

Adapun sebagai landasan syariahnya, diterangkan dalam Al-Qur'an sebagai berikut:

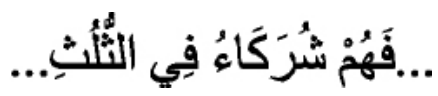

“... maka mereka berserikat pada sepertiga..." (Q.S. An-Nisa : 12)

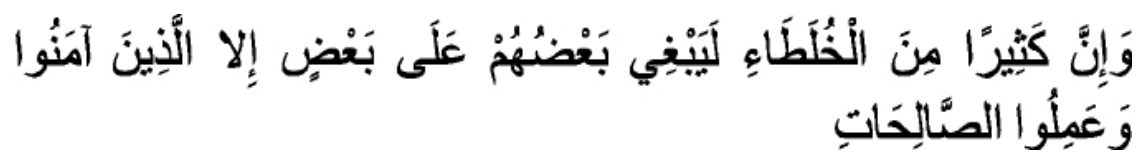

"Dan, sesungguhnya kebanyakan dari orang-orang yang berserikat itu sebagian mereka yang berbuat zalim kepada sebagian yang lain kecuali orang yang beriman dan mengerjakan amal saleh." (Q.S. Shaad : 24)

Kedua ayat di atas menunjukkan perkenan dan pengakuan Allah SWT. akan adanya perserikatan dalam kepemilikan harta. Hanya saja dalam 
surah An-Nisa: 12 perkongsian terjadi secara otomatis karena waris, sedangkan dalam surah Shaad: 24 terjadi atas dasar akad (Muhammad Syafi'i Antonio, 2009: 91).

Kemudian diterangkan pula dalam sebuah hadits Nabi Saw. dalam kitab Bulughul Maram (Ibnu Hajar al-Asqalani, 258 H:187) adalah sebagai berikut:

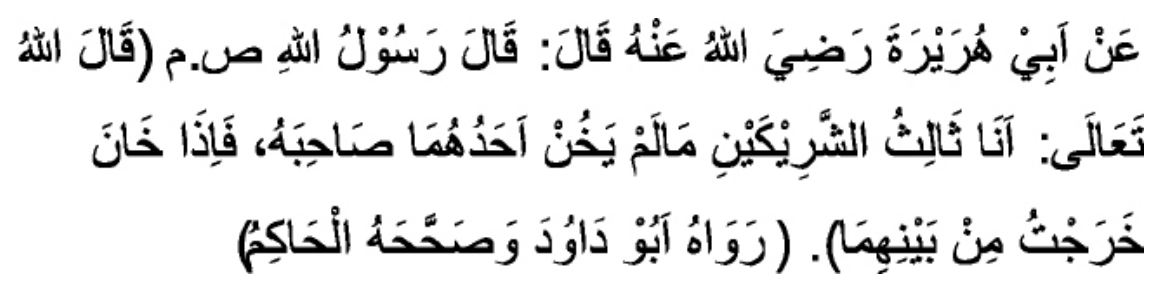

"Dari Abu Hurairah r.a, ia berkata: Telah bersabda Rasulullah Saw. : Allah Ta'ala berfirman: aku yang meniagai dua orang yang bersekutu selama salah seorang dari mereka tidak mengkhianati yang lainnya. Maka apabila ia berkhianat, Aku keluar dari antara mereka" (H.R. Abu Dawud dan shahkan oleh Hakim) (A. Hasan, 2006: 391).

Di dalam Islam sendiri konsep kerjasama lebih dikhususkan lagi dengan membagi kedalam beberapa bagian salah satunya adalah dengan adanya prinsip mudharabah. Mudharabah atau qiradh termasuk salah satu bentuk syirkah, menurut bahasa qiradh adalah potongan, sedangkan menurut istilah Dr. H. Hendi Suhendi, M.Si memberikan pengertian bahwa mudharabah atau qiradh ialah akad antara pemilik pemodal (harta) dengan pegelola modal tersebut, dengan syarat bahwa keuntungan diperoleh dua belah pihak sesuai jumlah kesepakatan (Suhendi, 2010: 138).

Akad (ikatan, keputusan, atau penguatan) atau perjanjian atau kesepakatan atau transaksi dapat diartikan sebagai komitmen yang terbingkai dengan nilai-nilai syariah (Ascarya, 2011: 35). Menurut istilah (terminologi), yang dimaksud dengan akad adalah perikatan ijab dan kabul yang dibenarkan syara' yang menetapkan keridhaan kedua belah pihak.

Landasan hukum dasar akad adalah sebagai berikut, Allah SWT. berfirman: 


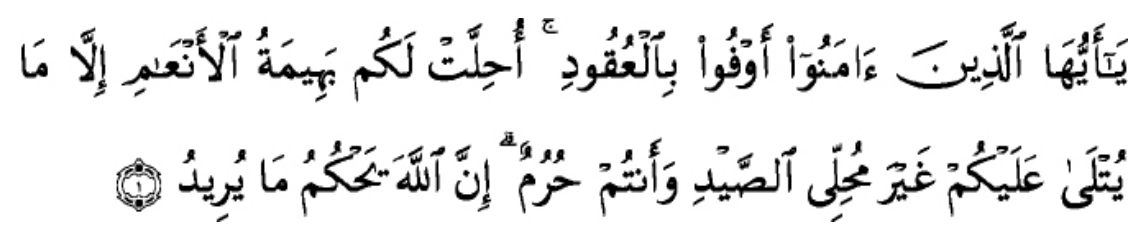

"Hai orang-orang yang beriman, penuhilah aqad-aqad itu. dihalalkan bagimu binatang ternak, kecuali yang akan dibacakan kepadamu (yang demikian itu) dengan tidak menghalalkan berburu ketika kamu sedang mengerjakan haji. Sesungguhnya Allah menetapkan hukum-hukum menurut yang dikehendakiNya." (Q.S. Al-Maidah : 1).

Adapun Rukun dan Syarat Akad antara lain:

1. Rukun-rukun Akad:

a. Ijab qabul

b. Pihak yang berakad (Aqid)

c. Benda yang diakadkan (objek akad) (Dimyauddin Djuwaini, 2010: 58).

2. Syarat-syarat Akad:

a. Kedua orang yang melakukan akad cakap bertindak (ahli). Tidak sah akad orang yang tidak cakap bertindak, seperti orang gila, orang yang berada di bawah pengampuan (mahjur) karena boros atau yang lainnya.

b. Yang dijadikan objek akad dapat menerima hukumnya.

c. Akad itu diizinkan oleh syara', dilakukan oleh orang yang mempunyai hak melakukannya walaupun dia bukan aqid yang memiliki barang.

d. Janganlah akad itu akad yang dilarang oleh syara', seperti jual beli musalamah.

e. Akad dapat memberikan faidah sehingga tidaklah sah bila rahn dianggap sebagai imbangan amanah.

f. Ijab itu berjalan terus, tidak dicabut sebelum terjadi kabul. Maka bila orang yang berijab menarik kembali ijabnya sebelum kabul, maka batallah ijabnya.

g. Ijab dan qabul mesti bersambung sehingga bila seseorang yang 
berijab sudah berpisah sebelum adanya kabul, maka ijab tersebut menjadi batal (Hendi Suhendi, 2010: 50).

Sedangkan larangan dalam akad muamalah antara lain:

1. Gharar (ketidakpastian)

2. Tadlis (transaksi dimana salah satu pihak tidak mengetahui informasi)

3. Terjadi Ta'alluq (tergantungnya suatu akad atas akad yang lain sehingga akad kedua menjadi rukun dari akad pertama)

4. Terjadi 2 in 1 (dua akad dalam satu transaksi)

5. Riba (meminta tambahan dari sesuatu yang dihutangkan)

6. Maysir (spekulasi)

7. Bathil (akad yang tidak memenuhi rukun dan syarat)

(http://www.wiziq.com/tutorial/52127-fiqh-muamalat)

Mengenai hukum dua akad dalam satu transaksi dinyatakan dalam hadits NabiSAW. yaitu Hadits yang diriwayatkan oleh Ahmad, an-Nasa'i dan dishahkan oleh at-Tirmidzi dan Ibnu Hibban, dari Abu Hurairah ra. yang menyatakan dalam kitab Bulughul Maram (al-Asqalani, $258 \mathrm{H}$ : 169) adalah sebagai berikut:

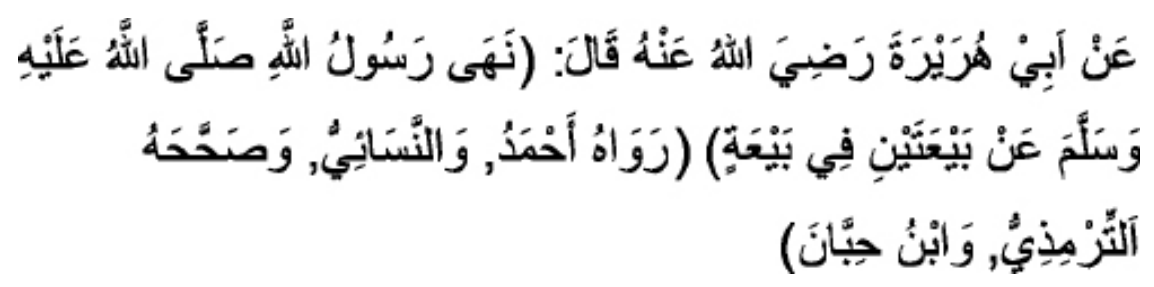

"Dari Abu Hurairah r.a, ia berkata: Rasulullah SAW. larang dua jual beli di dalam satu jual beli" (H.R. Ahmad, an-Nasa'i dan dishahkan oleh atTirmidzi dan Ibnu Hibban) (A. Hasan, 2006:349)

Maksud hadits ini, Rasulullah SAW. dengan tegas melarang praktek dua akad (kesepakatan) dalam satu akad (kesepakatan).

Bank adalah badan usaha yang menghimpun dana dari masyarakat dalam bentuk simpanan dan menyalurkanya kepada masyarakat dalam bentuk kredit dan/atau bentuk lainnya dalam rangka meningkatkan taraf 
hidup rakyat.

Untuk hal yang berhubungan dengan penghimpunan dana, di Bank Syariah dapat berbentuk giro, tabungan dan deposito. Prinsip opersional syariah yang diterapkan dalam penghimpunan dana masyarakat adalah prinsip Wadiah dan Mudharabah.

Dalam mengaplikasikan prinsip mudharabah, penyimpan atau deposan bertindak sebagai shahibul maal (pemilik modal) dan bank sebagai mudharib (pengelola). Dana tersebut digunakan bank untuk melakukan murabahah atau ijarah. Dapat pula dan tersebut digunakan bank untuk melakukan mudharabah kedua. Hasil usaha ini akan dibagi hasilkan berdasarkan nisbah yang disepakati. Dalam hal bank menggunakannya untuk melakukan mudharabah kedua, maka bank bertanggung jawab penuh atas kerugian yang terjadi. Prinsip mudharabah ini diaplikasikan pada produk tabungan berjangka dan deposito berjangka.

Berdasarkan kewenangan yang diberikan oleh pihak penyimpan dana, prinsip mudharabah terbagi dua yaitu: (Mudharabah Mutlaqah dan Mudharabah Muqayyadah). Dalam mudhrabah mutlaqah, tidak ada pembatasan bagi bank dalam menggunakan dana yang dihimpun. Nasabah tidak memberikan persyaratan pada apa pun kepada bank, ke bisnis apa dana yang disimpanya itu hendak disalurkan, atau menetapkan penggunaan akad-akad tertentu, atau pun mensyaratkan dananya diperuntukkan bagi nasabah tertentu. Jadi bank memiliki kebebasan penuh untuk menyalurkan dana ini ke bisnis manapun yang diperkirakan menguntungkan. Dari penerapan mudharabah mutlaqah ini dikembangkan produk tabungan dan deposito, sehingga terdapat dua jenis penghimpunan dana, yaitu tabungan mudharabah dan deposito mudharabah.

Ketentuan umum dalam produk ini adalah: 1) Bank wajib memberitahukan kepada pemilik dana mengenai nisbah dan tata cara pemberitahuan keuntungan dan/atau pembagian keuntungan secara resiko yang dapat ditimbulkan dari penyimpanan dana. Apabila telah tercapai kesepakatan, maka hal tersebut harus dicantumkan dalam akad; 2) Untuk tabungan mudharabah, bank dapat memberikan buku tabungan sebagai bukti penyimpanan, serta kartu ATM dan atau alat penarikan lainnya 
kepada penabung. Untuk deposito mudharabah, bank wajib memberikan sertifikat atau tanda penyimpanan (bilyet) deposito kepada deposan; 3) Tabungan mudharabah dapat diambil setiap saat oleh penabung sesuai dengan perjanjian yang disepakati, namun tidak tidak diperkenankan mengalami saldo negatif.

Sedangkan Ketentuan umum Tabungan berdasarkan Mudharabah dalam Fatwa Dewan Syariah Nasional Nomor 02/DSN-MUI/IV/2000: 1) Dalam transaksi ini nasabah bertindak sebagai shahibul maal atau pemilik dana, dan bank bertindak sebagai mudharib atau pengelola dana; 2) Dalam kapasitasnya sebagai mudharib, bank dapat melakukan berbagai macam usaha yang tidak bertentangan dengan prinsip syari'ah dan mengembangkannya, termasuk di dalamnya mudharabah dengan pihak lain; 3) Modal harus dinyatakan dengan jumlahnya, dalam bentuk tunai dan bukan piutang; 4) Pembagian keuntungan harus dinyatakan dalam bentuk nisbah dan dituangkan dalam akad pembukaan rekening; 5) Bank sebagai mudharib menutup biaya operasional tabungan dengan menggunakan nisbah keuntungan yang menjadi haknya; 6) Bank tidak diperkenankan mengurangi nisbah keuntungan nasabah tanpa persetujuan yang bersangkutan.

\section{Metode Penelitian}

Metode yang disajikan dalam pendahuluan ini hanya bersifat garis besar, sedangkan rinciannya dikemukakan pada bab selanjutnya. Adapun metode yang digunakan oleh penulis dalam penilitian ini adalah metode deskriptif. Metode deskriptif adalah suatu penelitian yang diupayakan untuk mencandra atau mengamati permasalahan secara sistematis dan akurat mengenai fakta-fakta dan sifat-sifat objek tertentu. Metode ini bertujuan melukiskan dan memahami kondisi objektif berkaitan dengan kinerja perbankan di PT. Bank Syariah Mega Indonesia Gallery Cianjur secara fenomologis dan apa adanya dalam konteks satu kesatuan yang integral (Saebani, 2008: 90).

Sumber data dalam penelitian ini terdiri dari sumber data primer dan data sekunder: a) Sumber data primer, yaitu sumber data yang diperoleh 
dari hasil wawancara langsung dengan karyawan PT. Bank Syariah Mega Indonesia Gallery Cianjur yaitu dengan Bapak R. Muhammad Ali Ridho (Relationship Officer). Data primer lainnya adalah dokumen yang berkaitan dengan Tabungan Rencana di PT. Bank Syariah Mega Indonesia Gallery Cianjur; b) Sumber data sekunder, yaitu sumber data tambahan yang berupa dokumen, arsip, buku-buku dan sebagainya, yang berkaitan dengan masalah yang diteliti dalam skripsi.

Sedangkan jenis data yang dibutuhkan dalam penelitian ini adalah jenis data kualitatif, yaitu terkait dengan data-data: a) Mekanisme, syarat dan ketentuan umum Tabungan Rencana di PT. Bank Syariah Mega Indonesia Gallery Cianjur; b) Data-data yang bersumber dari kitab, buku, penelitian dan lainnya tentang fikih muamalah seputar akad tabungan.

\section{Teknik Pengumpulan Data}

Adapun teknik pengumpulan data yang dilakukan penulis dalam penyusunan skripsi ini adalah meliputi:

a. Observasi

Suatu proses pengamatan dan pencatatan secara sistematis, logis, objektif dan rasional mengenai berbagai fenomena, baik dalam situasi yang sebenarnya maupun dalam situasi buatan untuk mencapai tujuan tertentu. Jadi hemat penulis, observasi ini dilakukan untuk menemukan data dan informasi dari gejala-gejala atau fenomena (kejadian-kejadian atau peristiwa-peristiwa) secara sistematis dan didasarkan pada tujuan penyelidikan yang telah dirumuskan. Pada observasi ini peneliti datang di tempat kegiatan orang yang diamati, tetapi tidak ikut terlibat dalam kegiatan tersebut dan dinamakan observasi partisipasi pasif (Saebani, 2008:187)

Berdasarkan hal itu, teknik ini dimaksudkan untuk mengetahui gambaran dari fenomena-fenomena yang terjadi di PT. Bank Syariah Mega Indonesia Gallery Cianjur.

b. Wawancara

Teknik pengumpulan data dengan mengajukan pertanyaan kepada responden, dan jawaban-jawaban responden dicatat atau direkam 
(Suryana dan Priatna, 2009: 200), yakni karyawan PT. Bank Syariah Mega Indonesia Gallery Cianjur. Wawancara diajukan secara lisan sesuai dengan jenis data yang dibutuhkan, dan untuk hal lain, apabila diperlukan, pertanyaan diajukan secara tertulis yang akan dijawab oleh pihak PT. Bank Syariah Mega Indonesia Gallery Cianjur secara tertulis juga.

c. Studi Dokumentasi

Mempelajari dan mengumpulkan data dari sejumlah literatur yang ada hubunganya dengan penelitian ini sebagai data teoritis untuk dijadikan acuan dalam penulisan skripsi ini.

\section{Analisa Data}

Dalam menganalisa data penulis melakukan tahapan-tahapan sebagai berikut:

a. Menelaah semua sumber data yang diperoleh baik dari sumber primer maupun sumber sekunder.

b. Melakukan klasifikasi terhadap data yang terkumpul sesuai dengan masalah yang diteliti.

c. Menghubungkan data-data yang diperoleh dengan teori yang sudah dikemukakan dalam kerangka pikiran.

d. Mengambil kesimpulan dari data-data yang dianalisis.

\section{Bentuk Aktivitas Usaha PT. Bank Syariah Mega Indonesia Gallery Cianjur}

Prinsip yang digunakan PT. Bank Syariah Mega Indonesia Gallery Cianjur:

1. Prinsip Mudharabah

Akad kerjasama usaha antara pemilik dana (shahibil maal) dan pengelola dana (mudharib) dengan pembagian keuntungan sesuai nisbah yang disepakati dari awal.

Dasar pemberian keuntungan: Bagi Hasil

Jenis Mudharabah:

a. Mudharabah Muthlaqah 
Shahibul maal memberikan kebebasan penuh kepada mudharib dalam pengelolaan investasinya.

b. Mudharanah Muqayyadah

Shahibul maal memberikan batasan kepada mudharib mengenai tempat, cara dan objek investasi.

2. Prinsip Wadiah

Titipan murni shahibul maal yang harus dijaga dan dikembalikan kapan saja menghendakinya.

Dasar pemberian keuntungan: Bonus

Jenis Wadiah:

a. Wadiah Yad Al Amanah

Titipan murni shahibul maal, dimana barang yang dititipkan tidak dapat digunakan/diambil manfaatnya oleh pengelola dana (mudharib).

b. Wadiah Yad Dhamanah

Titipan murni, dimana shahibul maal mengizinkan barang yang dititipkan dapat digunakan dan diambil manfaatnya, shahibul maal mendapatkan insentif berupa bonus yang tidak disyaratkan.

Pokok Fatwa DSN: Akad Produk

1. Tentang Giro: Giro ada dua jenis:

a. Yang tidak sesuai syariah, berdasarkan bunga

b. Yang sesuai syariah, berdasarkan wadiah dan mudharabah

2. Tentang Tabungan: Tabungan ada dua jenis:

a. Yang tidak sesuai syariah, berdasarkan bunga

b. Yang sesuai syariah, berdasarkan wadiah dan mudharabah

3. Tentang Deposito: Deposito ada dua jenis:

a. Yang tidak sesuai syariah, berdasarkan bunga

b. Yang sesuai syariah, berdasarkan mudharabah

Pokok Fatwa DSN: Mudharabah 
1. Nasabah sebagai shahibul maal, bank sebagai mudharib

2. Sebagai mudharib, bank dapat melakukan berbagai usaha untuk mengembangkan dana yang tidak bertentangan dengan syariah, termasuk bermudharabah dengan pihak lain

3. Modal harus dinyatakan jumlahnya dalam bentuk tunai dan tidak boleh dalam bentuk piutang

4. Pembagian keuntungan harus dinyatakan dalam bentuk nisbah dan dicantumkan dalam akad rekening

5. Sebagai mudharib bank menutup biaya operasional rekening dengan mempergunakan keuntungan yang menjadi bagianya

6. Bank tidak boleh mengurangi bagian keuntungan nasabah tanpa persetujuan yang bersangkutan.

Pokok Fatwa DSN: Wadiah

1. Bersifat titipan

2. Titipan harus dapat diambil kapan saja (on call basis)

3. Tidak boleh ada imbalan yang dipersyaratkan kecuali dalam bentuk pemberian yang bersifat sukarela dari pihak bank

4. Metode pemberian bonus dan mekanismenya tidak diatur

5. Spesifikasi on call basis yang diterapkan tidak diatur rinci

Sedangkan untuk aktivitas utama PT. Bank Syariah Mega Indonesia Gallery Cianjur di antaranya sebagai berikut:

1. Penghimpunan dana

Produk-produk PT. Bank Syariah Mega Indonesia Gallery Cianjur dalam penghimpunan dana antara lain sebagai berikut:

a. Tabungan Utama Mega Syariah

Tabungan yang berprinsip Wadiah yang disediakan untuk penyimpanan dana anda sesuai syariah.

Akad : Wadiah (Pemberian bonus tidak diperjanjikan diawal)

Landasan : Fatwa DSN MUI No.02/DSN-MUI/IV2000 


$$
\text { tentang Tabungan }
$$

b. Tabungan Rencana Mega Syariah

Tabungan perencanaan yang memiliki fleksibilitas tinggi dengan Akad Mudharabah yang dapat digunakan semua kegiatan sesuai dengan keinginan nasabah.

Akad : Mudharabah Muthlaqah

Landasan : Fatwa DSN MUI No.02/DSN-MUI/IV2000 tentang Tabungan

c. Tabungan Haji Mega Syariah

Tabungan yang ditujukan untuk nasabah yang akan menjalankan ibadah haji. Tabungan Haji Mega Syariah penuh kebaikan dan barokah serta memiliki berbagai fasilitas.

Akad : Mudharabah

Landasan : Fatwa DSN MUI No.02/DSN-MUI/IV2000 tentang Tabungan

d. Tabungan Plus Mega Syariah

Tabungan investasi yang dapat digunakan untuk tabungan transaksional dengan prinsip mudharabah.

Prinsip Produk : Mudharabah (investasi) 24\%

e. Tabungan Investasya Mega Syariah

Tabungan dengan prinsip mudharabah yang memberikan nisbah lebih tinggi untuk dana investasi yang lebih besar. Ditujukkan untuk nasabah perorangan ataupun perusahaan.

Prinsip Produk: Mudharabah (investasi) 24\%

f. Fleksi Plus Mega Syariah

Investasi yang sesuai dengan prinsip wadiah (titipan) dengan jangka waktu fleksibel (harian) sesuai kebutuhan dalam mata uang rupiah.

Akad : Wadiah

Landasan : Fatwa DSN MUI No.02/DSN-MUI/IV2000 tentang Tabungan 
g. Giro Utama Mega Syariah

Produk simpanan likuid jangka pendek sampai menengah dengan mekanisme titipan yang dapat diambil sewaktu-waktu oleh nasabah.

Akad : Wadiah

Landasan : Fatwa DSN MUI No.01/DSN-MUI/IV2000 tentang Giro

h. Deposito Plus Mega Syariah

Produk simpanan tidak likuid jangka pendek sampai menengah dengan tingkat keuntungan yang optimal dengan masa kontrak yang tertentu dan nominal penempatan yang juga tertentu.

Akad : Mudharabah Muthlaqah

Landasan : Fatwa DSN MUI No.03/DSN-MUI/IV2000 tentang Deposito

2. Dana Talangan

Dana Talangan Mega Syariah adalah pembiayaan yang dapat digunakan untuk mendapatkan porsi keberanggkatan haji.

Sedangkan untuk aktivitas usaha penyaluran dana dilakukan oleh Mitra Usaha Mega Syariah (Sumber: Wawancara pada tanggal 16 Mei 2011).

\section{Mekanisme Tabungan Rencana di PT. Bank Syariah Mega Indonesia Gallery Cianjur}

Tabungan adalah simpanan yang penarikanya hanya dapat dilakukan menurut syarat tertentu yang disepakati, tetapi tidak dapat ditarik dengan cek, bilyet giro dan atau alat lainnya yang dipersamakan dengan itu. Nasabah jika hendak mengambil simpananya dapat langsung ke bank dengan membawa buku tabungan, slip penarikan, atau melalui fasilitas ATM.

Dalam hal ini terdapat dua prinsip perjanjian Islam yang sesuai diimplementasikan dalam produk perbankan berupa tabungan, yaitu wadiah dan mudharabah. Pilihan terhadap produk ini tergantung motif dari 
nasabah. Jika motifnya hanya menyimpan saja maka bisa dipakai produk tabungan wadiah, sedangkan untuk memenuhi nasabah yang bermotif investasi atau mencari keuntungan maka tabungan mudharabah yang sesuai (Anshori, 2007: 87).

Dalam prakteknya produk Tabungan Rencana (mudharabah) yang terjadi di PT. Bank Syariah Mega Indonesia Gallery Cianjur adalah sebagai berikut:

1. Mengisi Form Aplikasi Nasabah Individual/Institusi

2. $\quad$ Mengisi Form Akad Wadiah (Tabungan Utama)

3. Mengisi Slip Setoran Awal

4. Mengisi Form Akad Mudharabah (Tabungan Rencana)

5. Nasabah Tabungan Rencana (mudharabah) secara rutin untuk melakukan transaksinya harus melalui buku rekening Tabungan Utama/ induk yang menggunakan akad wadiah.

6. Fasilitas Tabungan Rencana yaitu mendapatkan sertifikat sebagai tanda bukti kepemilikan buku tabungan dan rekening koran sebagai buku laporan.

Landasan hukum dalam produk Tabungan Rencana (mudharabah) di PT. Bank Syariah Mega Indonesia Gallery Cianjur adalah fatwa Dewan Syariah Nasional (DSN) Majelis Ulama Indonesia (MUI) dan itu hanya garis besarnya saja tidak sampai dengan permasalahan akad yang terjadi di PT. Bank Syariah Mega Indonesia Gallery Cianjur yaitu hanya fatwa DSN MUI yang mengenai tabungan dan prinsip mudharabah. Fatwa DSN No. 02/DSN-MUI/IV/2000 yang berbunyi:

Pertama : Tabungan ada dua jenis:

1. Tabungan yang tidak dibenarkan secara syari'ah, yaitu tabungan yang berdasarkan perhitungan bunga.

2. Tabungan yang dibenarkan, yaitu tabungan yang berdasarkan prinsip Mudharabah dan Wadi'ah.

Kedua : Ketentuan Umum Tabungan berdasarkan Mudharabah:

1. Dalam transaksi ini nasabah bertindak sebagai shahibul maal atau 
pemilik dana, dan bank bertindak sebagai mudharib atau pengelola dana.

2. Dalam kapasitasnya sebagai mudharib, bank dapat melakukan berbagai macam usaha yang tidak bertentangan dengan prinsip syari' ah dan mengembangkannya, termasuk di dalamnya mudharabah dengan pihak lain.

3. Modal harus dinyatakan dengan jumlahnya, dalam bentuk tunai dan bukan piutang.

4. Pembagian keuntungan harus dinyatakan dalam bentuk nisbah dan dituangkan dalam akad pembukaan rekening.

5. Bank sebagai mudharib menutup biaya operasional tabungan dengan menggunakan nisbah keuntungan yang menjadi haknya.

6. Bank tidak diperkenankan mengurangi nisbah keuntungan nasabah tanpa persetujuan yang bersangkutan.

Ketiga : Ketentuan Umum Tabungan berdasarkan Wadi'ah:

1. Bersifat simpanan.

2. Simpanan bisa diambil kapan saja (on call) atau berdasar-kan kesepakatan.

3. Tidak ada imbalan yang disyaratkan, kecuali dalam bentuk pemberian ('athaya) yang bersifat sukarela dari pihak bank.

Tinjauan Fikih Muamalah Terhadap Pelaksanaan Akad Produk Tabungan Rencana di PT. Bank Syariah Mega Indonesia Gallery Cianjur

Islam memandang bahwa bumi dan segala isinya merupakan amanah dari Allah kepada manusia sebagai khalifah di bumi, untuk dipergunakan sebenar-benarnya bagi kesejahteraan manusia.

Ajaran Islam telah dituangkan dalam Al-Qur'an dan Hadits Nabi Muhammad SAW. salah satunya adalah mengenai muamalah yang memberikan gambaran secara umum tentang hubungan manusia dengan manusia yang perlu dilakukan oleh umat Islam dalam kehidupan bermasyarakat, berbangsa dan bernegara. Sebagaimana firman Allah SWT. dalam surat An-Nisa ayat 29: 


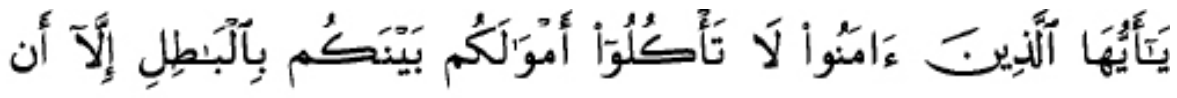

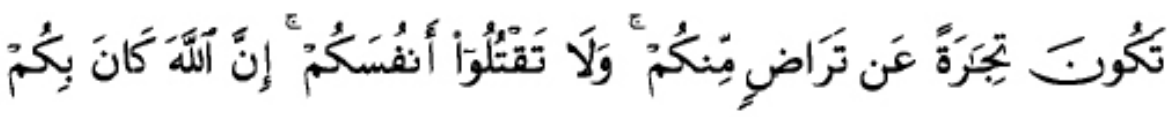

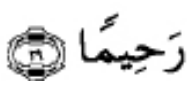

Produk-produk yang berada di PT. Bank Syariah Mega Indonesia Gallery Cianjur sudah seharusnya sesuai dengan apa yang telah ditentukan di dalam Al-Qur'an, Hadits dan Ijtihad yang menyangkut dengan masalah muamalah, walaupun sebenarnya tidak adanya batasan untuk masalah muamalah di dalam Islam selama tidak ada aturan yang melarangya. Dalam kaidah-kaidah fikih yang sering disebut dengan kaidah fikih muamalah berbunyi sebagai berikut:

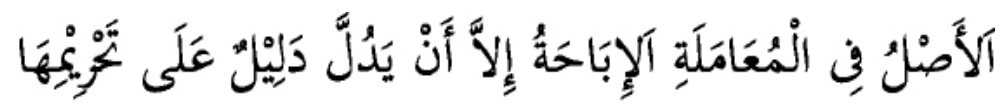

"Hukum asal dalam semua bentuk muamalah adalah boleh dilakukan kecuali ada dalil yang mengharamkanya" (A. Djazuli, 2007:130).

Oleh karena itu, disetiap bank syariah termasuk di PT. Bank Syariah Mega Indonesia Gallery Cianjur terdapatnya DPS (Dewan Pengawas Syariah) dalam rangka untuk meninjau apakah produk yang ada di bank yang bersangkutan telah sesuai dengan ketentuan fikih muamalah.

Pelaksanaan akad produk Tabungan Rencana (mudharabah) di PT. Bank Syariah Mega Indonesia Gallery Cianjur adalah ada dua akad dalam satu transaksi, bahwasanya produk Tabungan Rencana (mudharabah) dalam melakukan transkasinya harus melalui buku Tabungan Utama/ induk yang menggunakan akad wadiah. Penggunaan dua akad dalam satu transaksi secara bersamaan tidak dibenarkan secara syariah jika memenuhi tiga kondisi berikut:

1. Menyangkut pihak yang sama

2. Menyangkut objek yang sama

3. Dalam rentang waktu yang sama (Zulkifli, 2007: 23).

Mengenai hukum dua akad dalam satu transaksi dinyatakan dalam hadits Nabi SAW. yaitu Hadits yang diriwayatkan oleh Ahmad, an-Nasa'i 
dan dishahkan oleh at-Tirmidzi dan Ibnu Hibban, dari Abu Hurairah ra. yang menyatakan dalam kitab Bulughul Maram (al-Asqalani, 258H: 169) adalah sebagai berikut:

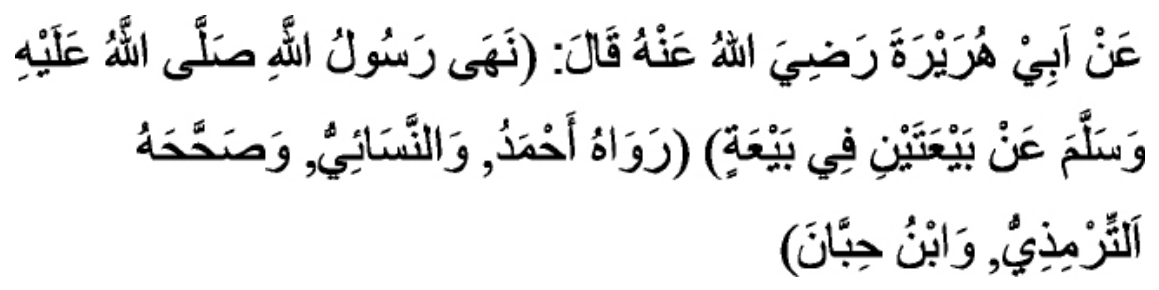

"Dari Abu Hurairah r.a, ia berkata: Rasulullah SAW. larang dua jual beli di dalam satu jual beli" (H.R. Ahmad, an-Nasa'i dan dishahkan oleh atTirmidzi dan Ibnu Hibban) (A. Hasan, 2006:349).

Rasulullah SAW. melarang (kaum muslimin) melakukan dua akad dalam suatu proses akad tertentu, demikian diriwayatkan oleh Ahmad tentang larangan Rasulullah SAW. Hadits ini maksudnya adalah tidak boleh seseorang melakukan dua akad berbeda dalam suatu proses muamalah tertentu.

Dalam prakteknya akad produk Tabungan Rencana (mudharabah) itu kelihatan seperti ada dua akad dalam satu transaksi, dari hasil penelitian bahwasanya dalam masalah mekanisme akad produk Tabungan Rencana di PT. Bank Syariah Mega Indonesia Gallery Cianjur adalah hanya prosedural dari bank dan sudah sesuai dengan fatwa DSN No. 02 dan tidak ada pelanggaran dalam fikih muamalah.

\section{Penutup}

Dari semua pembahasan skripsi ini, kiranya dapat disimpulkan hal-hal sebagai berikut:

1. Mekanisme Tabungan Rencana di PT. Bank Syariah Mega Indonesia Gallery Cianjur adalah (1) Mengisi form aplikasi nasabah Individual/ Institusi; (2) Mengisi form akad wadiah (Tabungan Utama); (3) Mengisi slip setoran awal; (4) Mengisi form akad mudharabah (Tabungan Rencana); (5) Nasabah Tabungan Rencana (mudharabah) 
secara rutin untuk melakukan transaksinya harus melalui buku rekening Tabungan Utama/induk yang menggunakan akad wadiah; (6) Fasilitas Tabungan Rencana yaitu mendapatkan sertifikat sebagai tanda bukti kepemilikan buku tabungan dan rekening koran sebagai buku laporan.

2. Landasan hukum dalam produk Tabungan Rencana (mudharabah) di PT. Bank Syariah Mega Indonesia Gallery Cianjur adalah Fatwa DSN No. 02/DSN-MUI/IV/2000 tentang Tabungan.

3. Menurut perspektif muamalah, Larangan dalam akad muamalah antara lain; (1) Gharar (ketidakpastian), (2) Tadlis (transaksi dimana salah satu pihak tidak mengetahui informasi), (3) Terjadi Ta'alluq (tergantungnya suatu akad atas akad yang lain sehingga akad kedua menjadi rukun dari akad pertama), (4) Terjadi 2 in 1 (dua akad dalam satu transaksi), (5) Riba (meminta tambahan dari sesuatu yang dihutangkan), (6) Maysir (spekulasi), (7) Bathil (akad yang tidak memenuhi rukun dan syarat). Pelaksanaan akad produk Tabungan Rencana di PT. Bank Syariah Mega Indonesia Gallery Cianjur dapat disimpulkan bahwa sudah sesuai dengan fatwa DSN No.02 dan tidak ada pelanggaran dalam fikih muamalah.

\section{DAFTAR PUSTAKA}

Anshori, Abdul Ghofur. 2007. Perbankan Syariah di Indonesia, Gadjah Mada University Press, Yogyakarta.

Karim, Adiwarman A.. 2010. Bank Islam Analisis Fiqih dan Keuangan, PT. RajaGrafindo Persada, Jakarta.

A. Djazuli. 2007. Kaidah-Kaidah Fikih, Prenada Media Group, Jakarta.

A. Hasan. 2006. Tarjamah Bulughul Maram, CV Penerbit Diponegoro, Bandung.

Soemitra, Andri. 2009. Bank \& Lembaga Keuangan Syariah, Prenada Media, Jakarta.

Ascarya. 2011. Akad dan Produk Bank Syariah, PT. RajaGrafindo Persada, Jakarta. 
Saebani, Beni Ahmad. 2008. Metode Penelitian, CV Pustaka Setia, Bandung

Departemen Agama RI. 2007. Al-Hikmah Al-Qur'an dan Terjemahnya, CV. Penerbit Diponegoro.

Djuwaini, Dimyauddin. 2010. Pengantar Fikih Muamalah, Pustaka Pelajar, Yogyakarta.

Hendi Suhendi. 2010. Fikih Muamalah, PT. RajaGrafindo Persada, Jakarta. Ibnu Hajar al-Asqalani. 258H. Bulughul Maram, Al-Azhar, Beirut.

Muhammad. 2009. Model-Model Akad Pembiayaan di Bank Syariah, UII Press, Yogyakarta.

Muhammad Syafi'i Antonio. 2009. Bank Syariah dari Teori ke Praktik, Gema Insani, Jakarta.

Sunarto Zulkifli. 2007. Perbankan Syariah, Zikrul Hakim, Jakarta.

Yaya Suryana dan Tedi Priatna. 2009. Metodologi Penelitian Pendidikan, Azkia Pustaka Utama, Bandung.

Zainuddin Ali. 2008. Hukum Perbankan Syariah, Sinar Grafika, Jakarta. 